\title{
TULOTASON VAIKUTUKSESTA ELINTARVIKEMENOIHIN JA KULUTUSMÄÄRIIN
}

\author{
PaAvo KaARLehto \\ Maatalouden taloudellinen tutkimuslaitos, Rukkila.
}

Saapunut 10. 12. 1960

Viimeksi kuluneina vuosina on maataloustuotteiden markkinatilanteelle luonteenomaisena piirteenä ollut jatkuva tasapainottomuus. Tuotannon lisäys on useilla tärkeillä aloilla ylittänyt tehokkaan kysynnän kasvun, mikä on johtanut hintatason laskuun. Näissä olosuhteissa on kaikkialla maailmassa ryhdytty kiinnittämään entistä suurempaa huomiota kulutuksen kehitystä koskevien ennusteiden laatimiseen käytettäväksi tuotantopolitiikan ohjeena. Kun kysymys on sangen tärkeä kansainvälisen kaupan kannalta, muodostettiin vuonna 1958 ECE:n ja FAO:n toimesta yhteinen työryhmä koko Eurooppaa koskevan tutkimuksen aikaansaamiseksi.

Kulutusta koskevat ennusteet perustetaan yleisesti väestönkasvun ohella tulojen nousun elintarvikkeiden kulutuksessa aikaansaamiin vaikutuksiin. Siten on luonnollista, että tarvittaisiin entistäkin täydellisempiä tietoja elintarvikkeiden kysynnän tulojoustoista. Maassamme ei toistaiseksi kuitenkaan ole suoritettu yhtenäisiä kaikkia tärkeimpiä ravintoaineita koskevia tutkimuksia, vaikka eräitä hajatietoja onkin käytettävissä. Tästä syystä joutui edellä mainitun työryhmän sihteeristö Suomen kohdalla turvautumaan vuoden 1949 kulutustutkimuksen lukuihin, joista FAO:n toimesta (3) laskettiin eräitä tärkeimpiä tulojoustoarvoja.

Kun olosuhteet tällöin eivät vielä olleet palautuneet täysin normaaleiksi ja kun sihteeristön käyttämässä tutkimusaineistossa ilmeni eräitä puutteellisuuksia, heräsi ajatus uuden laajemman joustotutkimuksen suorittamiseksi vuoden 1956 kulutustutkimuksen tietoja käyttäen. Sosiaalisen tutkimustoimiston taholta suhtauduttiin myönteisesti tähän ajatukseen, vieläpä suoritettiin huomattavasti työtä vaativia aineiston uudelleen lajitteluja nimenomaan tällaisen tutkimuksen tarpeisiin. FAO:n suostuttua korvauksetta huolehtimaan joustolaskujen teknillisestä suorittamisesta osoittautui ajatuksen toteuttaminen mahdolliseksi.

Tutkimustehtävään ryhdyttäessä oli ratkaistava kaksi tärkeää kysymystä: 1) millaista funktiotyyppiä olisi käytettävä tulojen ja kulutuksen vuorosuhdetta tutkittaessa ja 2) miten kulutustutkimusta varten kerätyistä tiedoista voitaisiin saada mahdollisimman homogeeninen aineisto tulojoustokertoimien määrittämistä varten. 
Funktioita valittaessa oli tutkimuksen tarkoituksella varsin ratkaiseva merktys. Kulutusennusteiden laadinnassa voidaan parhaiten käyttää sellaista mahdollisimman yksinkertaista mittaa tulojen ja kulutuksen vuorosuhteelle kuin tavanomaisen logaritmisen (tai semilogaritmisen) regressioyhtälön joustokertoimet. Kun $y_{i}$ :llä merkitään kulutusta henkeä kohden tutkimusryhmässä $i, x_{i}:$ llä ryhmän tuloja (kokonaistulot vähennettynä veroilla ja velkojen koroilla) ja $v_{\mathrm{i}}$ :llä satunnaisvirhettä, voidaan käytetyt yhtälöt kirjoittaa

(1) $\log y_{i}=a+b \log x_{i}+v_{i}$

ja semilogaritmisena

(2) $y_{i}=c+d \log x_{i}+v_{i}$

Edellisessä tapauksessa $\mathrm{b}$ ilmaisee suoraan kulutusjouston, jälkimmäisessä tapauksessa jousto $\left(\mathrm{b}^{*}\right)$ on laskettu kaavasta

(3) $\mathrm{b}^{*}=\frac{\mathrm{d}}{\mathrm{y}}$

Kulutuslukuja eri tuloluokissa tarkasteltaessa osoittautui kuitenkin, että nämä funktiotyypit eivät kaikkien tuotteiden kohdalla kuvaa a.o. riippuvaisuussuhdetta tyydyttävästi. Erityisen selvästi tämä seikka ilmeni runsaasti rasvaa sisältävien ravintoaineiden $\mathrm{mm}$. voin kohdalla. Tämän tuotteen kulutus nousee ilmeisestialuksi tulojen kasvaessa, mutta tietyn maksimitason jälkeen kulutusmäärät pienenevät tulojen jatkuvasti noustessa.

Jotta voitaisiin luoda käsitys siitä, missä määrin logaritmisten regressiofunktioiden käyttö saattaa olla harhaanjohtavaa, on voin kulutuksen ja tulojen keskinäisen vuorosuhteen kuvaamiseen esimerkkiluontoisesti sovellettu myös paraabelifunktiota (4) sekä log-log-inverssifunktiota (5).

(4) $y_{i}=a+b x_{i}+c x_{i}^{2}+v_{i}$

(5) $\log y_{i}=a-b \log x_{i}-\frac{c}{x_{i}}+v_{i}$

Kuviossa 1 on esitetty 2-lapsisten työläisperheiden voin kulutusmäärät henkeä kohden kuukaudessa kussakin tuloluokassa sekä näiden havaintojen perusteella laskettujen em. funktioiden kuvaajat, jotka erityisesti tulotason ääriarvojen kohdalla poikkeavat toisistaan huomattavasti. Tällaisissa tapauksissa saattavat yksinkertaisista logaritmifunktioista laskettujen joustokertoimien arvot muodostua harhaanjohtaviksi ennusteita silmälläpitäen. Esillä olevassa tapauksessa ei ero ole funktioiden (1) ja (4) keskimääräisen arvon kohdalla suuri. Voin kysynnän tulojouston estimaatti logaritmifunktion mukaan on 0.28 ja paraabelifunktion perusteella laskettuna maan keskimääräisen tuloluokan (n. $175000 \mathrm{mk} /$ asukas) kohdalla n. 0.23. Funktiotyyppiä (5) käytettäessä on ero suurempi; joustokertoimeksi saadaan 0.16.

Käytettäessä keskimääräisiä tulojoustolukuja kulutusennusteiden perustana, on ilmeisesti syytä kiinnittää huomiota siihen, minkä tuloluokkien kohdalla kohoamista on odotettavissa. Jos meidän oloissamme taloudellinen aktiviteetti lisääntyy, mikä usein ilmenee erityisen voimakkaasti alempien tuloluokkien tulojen nousuna työllisyyden paranemisen johdosta, muodostuu vaikutus kulutukseen todennäköisesti suuremmaksi kuin mitä keskimääräiset joustoluvut edellyttäisivät. 
Kulutus kg/henk.

Consumption $\mathrm{kg}$ per capita

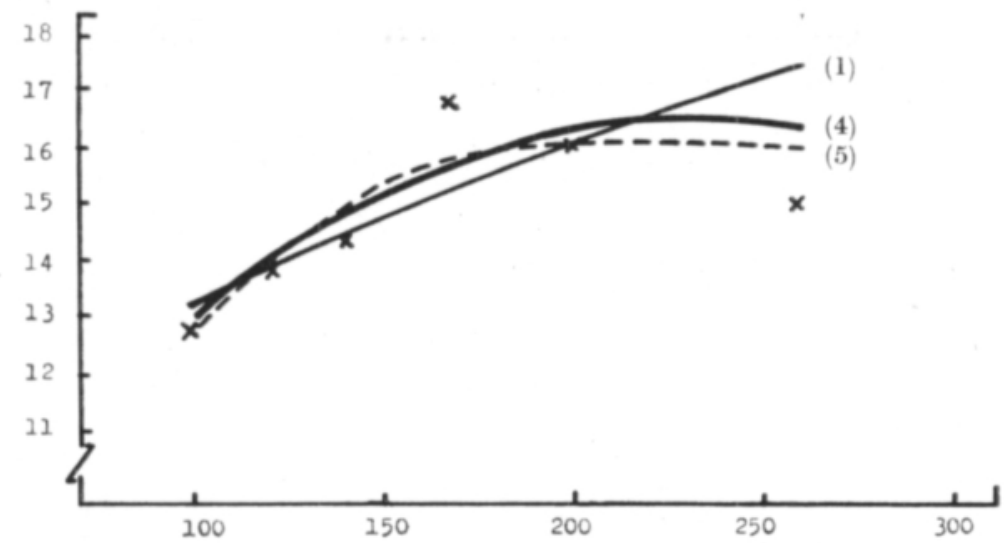

Kuvio 1. Voin kulutuksen riippuvuus tulotasosta.
Tulotaso $1000 \mathrm{mk} / \mathrm{henk}$. Income Thousand marks per capita

Figure 1. Relationship between butter consumption and income.

Käytettäessä kulutustutkimusaineistoa joustokertoimien määrittämiseen on erityistä huomiota kiinnitettävä tutkimuksessa mukana olleiden perheiden sosiaaliseen ryhmittämiseen ja perheen suuruuteen eri tuloluokissa kuten useat tutkijat (vrt. esim. 1, 2 ja 3) ovat todenneet. Jos aineistossa on esimerkiksi suhteellisen korkeaa kulutustasoa edustava ruumiillista työtä tekevien ryhmä alhaisemmalla tulotasolla kuin henkistä työtä tekevien ryhmä, ei koko aineistoa tarkasteltaessa saada oikeaa kuvaa tulojen kohoamisen vaikutuksesta ravintoaineiden käyttöön, vaan tulojoustokertoimet muodostuvat liian alhaisiksi. Tällaisten virhemahdollisuuksien välttämiseksi olisi laskelmat suoritettava sosiaaliseen ryhmittelyyn perustuvasta luokitellusta aineistosta. Mainittakoon tässä kohdin esimerkkinä uudelleen voi, jonka tulojoustokertoimeksi koko aineiston 2-lapsiperheistä saadaan kaksoislogaritmifunktiosta 0.18 , kun työläisperheiden vastaava arvo on 0.28 .

Vastaavasti saattaa virhettä joustokertoimiin aiheutua eri kokoisten perheiden kulutustasossa esiintyvistä eroista johtuen, jos laskelmia ei perusteta luokiteltuun aineistoon. Erittäin selvänä esimerkkinä näiden tekijöiden vaikutuksesta voidaan mainita juuston tulojoustoluvut. Kaksoislogaritmifunktioita käyttäen saatiin määräjoustoksi koko aineistosta 1.00, kaikkien 2-lapsiperheiden aineistosta 0.68 ja 2-lapsisten työläisperheiden aineistosta laskien tilastollisesti ei merkitsevä 0.09 .

Käytännössä on vuoden 1956 kulutustutkimuksessa mukana olleiden perheiden jaottelu kuitenkin suhteellisen vaikeata. Ensinnäkin on huomattava, että tutkimuksessa mukana olleiden perheiden lukumäärä 485 ei salli kovin pitkälle menevää ryhmittelyä. Lisäksi ovat perusteet aineiston jakamiseksi sosiaalisiin ryhmiin tällaista tutkimusta silmälläpitäen vajavaiset. Kun ruoka-aineiden kulutusta koskeva aineisto ei ole reikäkorteilla, olisi tarvittavien täydellisten perustietojen laskeminen muodostetuista ryhmistä vaatinut kohtuuttoman paljon työtä erityisesti siitä syystä, että aineisto on peruskäsittelyssä jaettu vain neljään tuloluokkaan. 
Jotta voitaisiin tarkastella lähemmin perheen koon merkitystä esillä olevan tehtävän kannalta, on jälleen valittu esimerkiksi eräs hyödyke, kananmunat, jonka kohdalla vaikutukset tulevat varsin selvästi näkyviin. Aineisto on tällöin ryhmitelty lapsettomiin pariskuntiin sekä yksi-, kaksi- ja kolmilapsisiin perheisiin. Kussakin luokassa on laskettu jousto määrien suhteen kaksoislogaritmifunktiota käyttäen. Kuviossa 2 on esitetty kunkin ryhmän kysyntäfunktioiden kuvaajat $R_{1}, R_{2}, R_{3}$ ja $\mathrm{R}_{4}$.

Kulutus kg/henk.

Consumption $\mathrm{kg}$ per capita

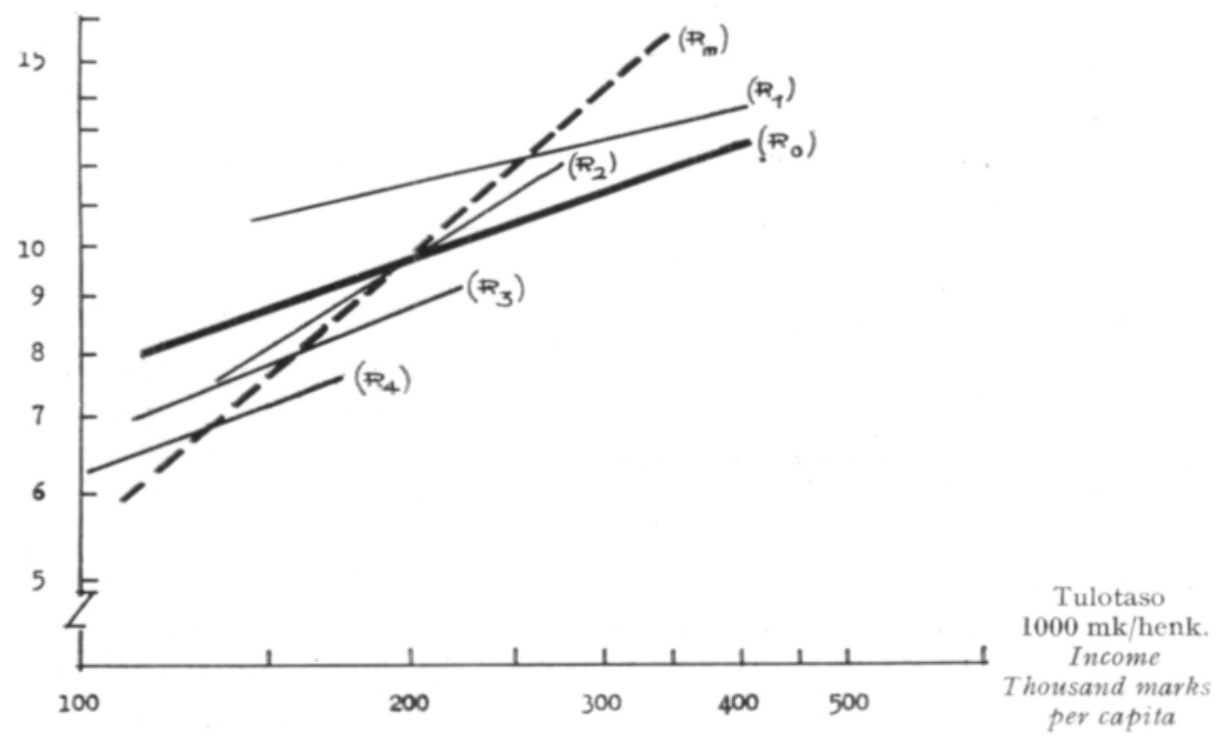

Kuvio 2. Kananmunien kulutuksen riippuvuus perheen koosta ja tulotasosta.

Figure 2. Relationship between egg consumption and income in different household size classes.

Kuviosta voidaan jo silmämääräisesti panna merkille, että perheen koon ja henkeä kohti laskettujen tulojen välillä vallitsee negatiivinen korrelaatio. Toiseksi voidaan todeta (vrt. suora $R_{m}$, joka on laskettu eri perheluokkien keskimääräistä kulutusta osoittavien pisteiden kautta), että myös henkeä kohti lasketun keskimääräisen kulutustason ja perheen koon välillä vallitsee jopa lineaarinen negatiivinen korrelaatio, kun tässä on jätetty yksinäiset henkilöt tarkastelun ulkopuolelle. Sensijaan ei regressiosuorien kaltevuudessa ole havaittavissa kovin suuria eroja.

Tällaisen aineiston tilastollinen käsittely ja joustokertoimien vertailu voidaan suorittaa tavanomaisesti kovarianssianalyysiä käyttäen (vrt. esim. GoREux, 3). Keskimääräinen kulutusjousto $\left(b_{o}\right.$ regressiosuorasta $R_{o}$ ) saadaan punnitsemalla eri perheluokissa kulutusjoustot $\left(b_{j}\right)$ vastaavilla, riippumattoman muuttujan $x$ variansseilla $(\mathrm{VW})_{\mathrm{j}}$.

(5) $b_{o}(V W)=\Sigma_{j}(V W)_{j} \cdot b_{j}$, jossa

(6) $\mathrm{VW}=\sum_{\mathrm{i}}(\mathrm{VW})_{\mathrm{j}}$ 
Luokkien keskipisteiden muodostamasta aineistosta lasketaan tavanomaista regressiomenetelmää käyttäen joustavuuskerroin $b_{m}$.

Edelleen lasketaan joustokerroin $\mathrm{b}_{\mathrm{a}}$ koko aineistosta, siis ottamatta huomioon luokkajakoa. Se saadaan helposti $b_{\mathrm{o}}: \mathrm{n}$ ja $\mathrm{b}_{\mathrm{m}}: \mathrm{n}$ punnittuna keskiarvona:

(7) $(\mathrm{VW}+\mathrm{VB}) \mathrm{b}_{\mathrm{a}}=(\mathrm{VW}) \mathrm{b}_{\mathrm{o}}+(\mathrm{VB}) \mathrm{b}_{\mathrm{m}}$, jossa VW on luokkien kokonaisvarianssi ja VB luokkien keskipisteiden välinen varianssi. Yleensä jako on sellainen, että $(V B)<(V W)$, jolloin $b_{a}$ on lähempänä $b_{o}: n$ kuin $b_{m}: n$ arvoa. Kertoimien $b_{j}, b_{a}, b_{m}$ ja $b_{o}$ estimaatit käyvät ilmi seuraavasta asetelmasta.

$\begin{array}{ccc}\begin{array}{c}\text { Perheiden } \\ \text { lukumäärä }\end{array} & \begin{array}{l}\text { Vapaus- } \\ \text { asteet }\end{array} & \begin{array}{c}\text { Regressio- } \\ \text { kertoimet }\end{array}\end{array}$

$\begin{array}{lrl}\mathrm{n}_{{ }_{1}}=105 & 2 & \mathrm{~b}_{1}=0.23 \\ \mathrm{n}_{\cdot_{2}}=117 & 2 & \mathrm{~b}_{2}=0.63 \\ \mathrm{n}_{\cdot_{2}}=86 & 1 & \mathrm{~b}_{3}=0.39 \\ \mathrm{n}_{4}=46 & 1 & \mathrm{~b}_{4}=0.34 \\ \mathrm{n}_{.}=354 & 9 & \mathrm{~b}_{0}=0.40 \\ & 2 & \mathrm{~b}_{\mathrm{m}}=0.84 \\ & 12 & \mathrm{~b}_{\mathrm{a}}=0.53\end{array}$

Kuten edellä todettiin silmämääräisesti kuviosta ei eri luokkien joustoarvoissa $b_{j}$ ole suuria eroja kerrointa $b_{2}$ lukuunottamatta. Erojen merkitsevyys voidaan selvittää F-testiä käyttäen seuraavasti:

Määritetään aineiston kokonaisvarianssin estimaatti $Q_{1}$ kunkin luokan regressiosuorasta laskettujen neliöpoikkeaminen summien yhteenlasketun arvon $\mathrm{S}_{1}$ ja vapausasteiden luvun $\mathrm{V}_{1}$ avulla $\left(\mathrm{Q}_{1}=\frac{\mathrm{S}_{1}}{\mathrm{~V}_{1}}\right)$. Regressiokertoimen $\mathrm{b}_{\mathrm{j}}$ välistä varianssia mitataan $\mathrm{Q}_{2}$ :lla, joka saadaan kertoimien $\mathrm{b}_{\mathrm{o}}$ ja $\mathrm{b}_{\mathrm{j}}$ välisten erojen neliöpoikkeamien summan $\mathrm{S}_{2}$ sekä a.o. vapausasteiden lukumäärän perusteella $\left(\mathrm{Q}_{2}=\frac{\mathrm{S}_{2}}{\mathrm{~V}_{2}}\right)$. Osamäärän $\frac{Q_{2}}{Q_{1}}$ avulla voidaan nyt selvittää, eroavatko joustokertoimet merkitsevästi toisistaan. Kuten seuraavasta asetelmasta ilmenee, jää varianssiosamäärä $\mathrm{F}_{0.95}$-arvoa alhaisemmaksi, joten kertoimissa ei ole merkitsevää eroa.

\begin{tabular}{ccccc}
$\begin{array}{c}\text { Vapaus- } \\
\text { asteet }\end{array}$ & $\begin{array}{c}\text { Neliö- } \\
\text { summat }\end{array}$ & $\begin{array}{c}\text { Vari- } \\
\text { anssit }\end{array}$ & $\begin{array}{c}\text { Varianssi- } \\
\text { osamäärä }\end{array}$ & $F_{0.95}$ \\
\hline $\mathrm{V}_{1}=6$ & $\mathrm{~S}_{1}=\mathbf{0 . 1 8 8}$ & $\mathrm{Q}_{1}=0.0315$ & $\mathrm{Q}_{2}=1.467$ & 4.76 \\
$\mathrm{~V}_{2}=3$ & $\mathrm{~S}_{2}=0.139$ & $\mathrm{Q}_{2}=0.0462$ & $\mathrm{Q}_{1}$ &
\end{tabular}

Seuraavana tehtävänä on tutkia perheen kokoluokkien kulutustasoissa esiintyvien erojen merkitsevyyttä. Kun $b_{j}:$ tten välillä ei ole merkitsevää eroa, voidaan kokonaisvarianssina regressiosuorista käyttää estimaattia $Q_{12}$, mikä ilmaisee kokonaisvarianssin regressiosuorista, jotka kulkevat kunkin luokan keskipisteen kautta ja joiden kulmakerroin on $\mathrm{b}_{\mathrm{o}}$ eli $\left(\mathrm{Q}_{12}=\frac{\mathrm{S}_{1}+\mathrm{S}_{2}}{\mathrm{~V}_{1}+\mathrm{V}_{2}}\right)$. 
Vertaamalla kertoimien $b_{o} j a b_{m}$ välisen eron jäännösvarianssia $Q_{4}$ edellä laskettuun kokonaisvarianssiin $Q_{12}$ voidaan todeta merkitsevien kulutustasoerojen olemassaolo, koska varianssiosamäärä $\frac{\mathrm{Q}_{4}}{\mathrm{Q}_{12}}$ on vastaavaa $\mathrm{F}_{0.95}$ arvoa suurempi

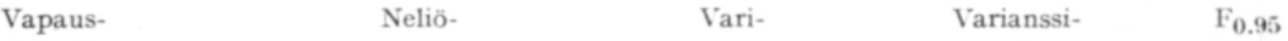

asteet summat anssit osamärä

$\mathrm{V}_{1}+\mathrm{V}_{2}=9 \quad \mathrm{~S}_{1}+\mathrm{S}_{2}=0.327$

$\mathrm{V}_{2}=1$

$\mathrm{S}_{4}=0.414$
$Q_{12}=0.0364$

$Q_{4}=0.4130$
$\frac{Q_{4}}{Q_{12}}=11.37$

5.12

Näin todettu merkitsevä tulos osoittaa, ettei luokittelemattomatonta aineistoa voida tässä tapauksessa käyttää regressiosuoran määrittämiseen. Joustokertoimeksi on valittava $b_{o}=0.40$. Seuraavassa esitettävää silmälläpitäen on syytä panna merkille, että näin saatu arvo on varsin lähellä 2-lapsiperheiden kulutusjoustokerrointa 0.39 .

Näin saatuja joustokertoimia ei kuitenkaan voida pitää täysin tyydyttävinä, koska ne ovat perustuneet vain perheen koon perusteella luokiteltuun aineistoon. Tämän ohella myös sosiaalinen ryhmittely olisi ollut tarpeellista. Kun kulutuslukujen laskeminen kaikista sosiaalisesti ryhmitellyn aineiston eri perheen suuruusluokista olisi vaatinut kohtuuttomasti työtä, selvitettiin Sosiaalisessa tutkimustoimistossa joustokertoimien määrittämistä varten erikseen vain 2-lapsiperheiden kulutusta koskevat tiedot a) koko aineistosta b) työläisperheistä, jotta voitaisiin päätellä, missä määrin kokonaisaineistosta lasketut kertoimet mahdollisesti sisältävät em. tekijöistä aiheutuvaa virhettä.

Kulutusmäärien ja rahamenojen suhteen erikseen lasketut joustokertoimet, jotka esitetään oheisissa taulukoissa, on laskettu vain kaksoislogaritmista ja semilogaritmista funktiotyyppiä käyttäen. Aineiston suppeuden vuoksi ei ole katsottu mahdolliseksi eri funktiomuotojen laajempaa käsittelyä, vaikka tämän kirjoituksen alussa esitetyt laskelmat antavatkin viitteitä niiden merkityksestä ainakin tietyissä tapauksissa.

Taulukoissa esitetyt kertoimet on laskettu FAO:n tilastokoneilla. Tulosten vertailun helpottamiseksi on taulukkoon 7 kerätty kaikki joustokertoimet. Kun tämän numeroaineiston yksityiskohtainen esittely ei liene tarkoituksenmukaista, on tyydytty muutamaan yleisluontoiseen tulosten arvostelua koskevaan huomautukseen.

Tarkasteltaessa kaksois- ja semilogaritmisten funktioiden antamia joustokertoimia voidaan niissä havaita varsin suuri yhdenmukaisuus. Estimaattien ero (b*b) absoluuttisesti ilmaistuna on $79 \%$ :ssa kaikista tapauksista alle \pm 0.1 ja suhteellinen ero $\frac{\left(\mathrm{b}^{*}-\mathrm{b}\right)}{\mathrm{b}^{*}}$ on $63 \%$ :ssa alle $\pm 10 \%$. Erot koko aineistosta ja 2-lapsiperheistä sekä 2-lapsisista työläisperheistä lasketuissa joustokertoimissa ovat sensijaan huomattavampia. Niinpä koko aineistosta ravintomenoille yhteensä saatu joustokertoimen estimaatti poikkeaa merkitsevästi kahdesta viimeksimainitusta. Myös kaikkien 2-lapsiperheiden ja työläisperheiden jostokertoimien estimaateissa esiintyy merkitseviä eroja runsaasti. Tyypillisinä esimerkkeinä näistä ovat mm. vihannekset ja he- 
delmät sekä toisaalta lihatuotteet. Ensinmainituissa ovat kaikkien 2-lapsiperheiden joustokertoimet korkeampia, mikä todennäköisesti johtuu tuloluokittelun yläpäässä olevan palvelus- ja virkahenkilökunnan suhteellisen korkeasta kulutustasosta. Lihatuotteiden kohdalla on tilanne aivan päinvastainen.

Edellä esitetyn perusteella voidaan yleisesti todeta, että luotettavien tutkimusten teko tulotasossa tapahtuvien muutosten vaikutuksesta elintarvikemenoihin ja kulutusmääriin asettaa varsin suuret vaatimukset perusaineistolle, sekä aineiston laajuuteen, että sen ryhmittelymahdollisuuksiin nähden. Aineistossa tulisi olla mahdollisuus perheiden sosiaaliseen ryhmittelyyn sekä näissä edelleen alaryhmittelyyn lapsiluvun mukaan. Lisäksi tarvittaisiin kulutusfunktioiden muodon määrittämiseksi ryhmittely vähintään kuuteen, mieluimmin kymmeneen tuloluokkaan.

\section{Yhteenveto}

Esillä olevassa tutkimuksessa on pyritty selvittämään eräiden hyödykkeiden kulutusmäärien ja niiden ostoon käytettyjen rahamenojen riippuvuutta tulojen suuruudesta vuoden 1956 kulutustutkimuksessa kerätyn aineiston perusteella. Suoritetuissa laskelmissa on osoittautunut, että erityisesti runsaasti rasvaa sisältävien ravintoaineiden tulojoustokertoimien määrityksissä tavanomaiset kaksoislogaritmiset tai semilogaritmiset kysyntäfunktiot eivät ehkä parhaalla mahdollisella tavalla kuvaa k.o. riippuvuussuhteita. Lisäksi on kulutustutkimuksessa kerätyn aineiston luokittelu sekä perheen koon, että sosiaalisen ryhmän perusteella osoittautunut välttämättömäksi. Kun tällaista luokittelua ei ole voitu toteuttaa esillä olevassa aineistossa, on vertailua varten laskettu joustokertoimet erikseen koko luokittelemattomasta aineistosta, kaikista kaksilapsiperheistä sekä kaksilapsisista työläisperheistä. Laskelmien teknillisestä suorituksesta on huolehtinut FAO. Yhteenveto saaduista tuloksista on esitetty taulukossa 7 . 
Taulukko 1. Rahamenojousto

Table 1. Expenditure elasticity

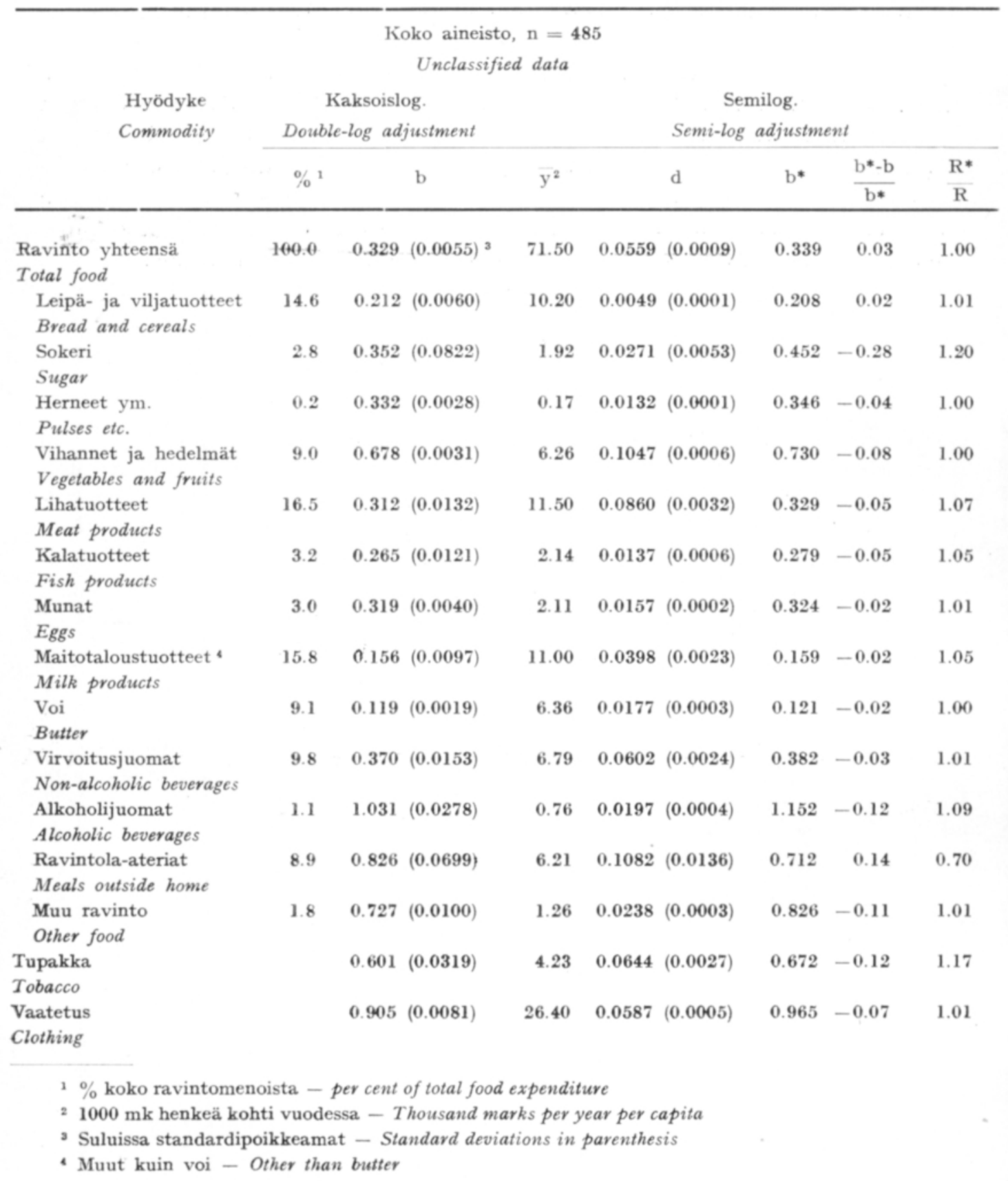


Taulukko 2. Määräjousto

Table 2. Quantity elasticity

Koko aineisto, $\mathrm{n}=485$

Unclassified data

Hyödyke

Commodity
Kaksoislog.

Double-log adjustment
Semilog.

Semi-log adjustment

$\bar{y}^{5} \quad \mathrm{~b} \quad \mathrm{~d} \quad \mathrm{~b}^{*} \frac{\mathrm{b}^{*}-\mathrm{b}}{\mathrm{b}^{*}} \frac{\mathrm{R}}{\mathrm{R}}$

\section{Vehnä}

Wheat

Riisi

Rice

Muu vilja

Other cereals

Peruna

Potatoes

Sokeri

Sugar

Herneet

Pulses

Tuoreet vihannekset

Fresh vegetables

Tuoreet hedelmät

Fresh fruits

Kuivat hedelmät

Dried fruits

Naudan- ja vasikanliha

Beef and veal

Lampaanliha

Mutton

Teurastuotteet

Offal

Munat

Eggs

Kala

Fish

Juusto

Cheese

Voi

Butter

Kerma

Cream

Eläinrasvat

Animal fats

Margariini

Margarine

Henkilöluku perheessä

No. of persons per family

\begin{tabular}{|c|c|c|c|c|c|c|c|}
\hline 50.60 & -0.018 & $(0.0039)^{3}$ & -0.0022 & $(0.0005)$ & -0.019 & 0.05 & 1.03 \\
\hline 3.12 & -0.211 & $(0.0105)$ & -0.0150 & $(0.0008)$ & -0.207 & -0.02 & 0.96 \\
\hline 32.10 & -0.130 & $(0.0046)$ & -0.0094 & $(0.0003)$ & -0.127 & -0.02 & 0.98 \\
\hline 78.90 & -0.149 & $(0.0172)$ & -0.0279 & $(0.0028)$ & -0.156 & 0.04 & 1.12 \\
\hline 30.80 & -0.091 & $(0.0031)$ & -0.0064 & $(0.0002)$ & -0.090 & -0.01 & 0.98 \\
\hline 1.61 & 0.236 & $(0.0058)$ & 0.0090 & $(0.0002)$ & 0.243 & 0.03 & 1.01 \\
\hline 13.80 & 0.195 & $(0.0090)$ & 0.0063 & $(0.0003)$ & 0.199 & 0.02 & 1.04 \\
\hline 26.90 & 0.750 & $(0.0044)$ & 0.0494 & $(0.0003)$ & 0.798 & 0.06 & 1.00 \\
\hline 1.83 & -0.468 & $(0.0171)$ & -0.0191 & $(0.0008)$ & -0.447 & -0.05 & 0.94 \\
\hline 17.30 & 0.342 & $(0.0173)$ & 0.0142 & $(0.0006)$ & 0.361 & 0.05 & 1.10 \\
\hline 0.69 & 0.170 & $(0.0321)$ & 0.0245 & $(0.0059)$ & 0.151 & -0.13 & 0.81 \\
\hline 1.03 & 0.304 & $(0.0227)$ & 0.0761 & $(0.0049)$ & 0.323 & 0.06 & 1.12 \\
\hline 8.51 & 0.322 & $(0.0036)$ & 0.0643 & $(0.0007)$ & 0.329 & 0.02 & 1.01 \\
\hline 10.40 & -0.031 & $(0.0094)$ & -0.0083 & $(0.0022)$ & -0.035 & 0.11 & 1.11 \\
\hline 2.87 & 0.999 & $(0.0085)$ & 0.0719 & $(0.0006)$ & 1.099 & 0.09 & 1.00 \\
\hline 16.40 & 0.140 & $(0.0022)$ & 0.0054 & $(0.0001)$ & 0.143 & 0.02 & 1.00 \\
\hline 8.91 & 0.322 & $(0.0059)$ & 0.0666 & $(0.0012)$ & 0.324 & 0.01 & 1.01 \\
\hline 0.35 & -0.491 & $(0.0585)$ & -0.0558 & $(0.0046)$ & -0.672 & 0.27 & 1.40 \\
\hline 5.74 & -0.088 & $(0.0176)$ & -0.0123 & $(0.0023)$ & -0.094 & 0.06 & 1.07 \\
\hline & 0.267 & $(0.0549)$ & 0.0170 & $(0.0030)$ & 0.250 & -0.07 & 1.16 \\
\hline
\end{tabular}

' Kiloa henkeä kohti vuodessa - Kilogram per capita per year 
Taulukko 3. Rahamenojousto

Table 3. Expenditure elasticity

Kaikki 2-lapsiperheet, $\mathrm{n}=105$

All families with 2 children

\begin{tabular}{|c|c|c|c|c|c|c|c|c|c|}
\hline \multirow{3}{*}{$\begin{array}{l}\text { Hyödyke } \\
\text { Commodity }\end{array}$} & \multirow{2}{*}{\multicolumn{3}{|c|}{$\begin{array}{l}\text { Kaksoislog. } \\
\text { Double-log adjustment }\end{array}$}} & \multicolumn{6}{|c|}{ Semilog. } \\
\hline & & & & \multirow[b]{2}{*}{$\bar{y}^{2}$} & \multicolumn{4}{|c|}{ Semi-log adjustment } & \multirow[b]{2}{*}{$\begin{array}{r}\mathrm{R}^{*} \\
\mathrm{R} \\
\end{array}$} \\
\hline & $\%{ }^{1}$ & \multicolumn{2}{|r|}{$\mathrm{b}$} & & & d & $b^{*}$ & $\frac{b^{*}-b}{b *}$ & \\
\hline Ravinto yhteensä & 100.0 & 0.420 & $(0.025)^{3}$ & 65.30 & 0.026 & $(0.002)$ & 0.433 & 0.03 & 0.97 \\
\hline Total food & & & & & & & & & \\
\hline $\begin{array}{l}\text { Leipä- ja viljatuotteet } \\
\text { Bread and cereals }\end{array}$ & 14.4 & 0.093 & $(0.044)$ & 9.41 & 0.008 & $(0.004)$ & 0.093 & 0.00 & 1.05 \\
\hline Sokeri & 6.2 & 0.354 & $(0.059)$ & 4.02 & 0.017 & $(0.003)$ & 0.460 & 0.23 & 0.96 \\
\hline Sugar & & & & & & & & & \\
\hline $\begin{array}{l}\text { Herneet ym. } \\
\text { Pulses }\end{array}$ & 0.3 & 0.603 & $(0.081)$ & 0.21 & 0.203 & $(0.050)$ & 1.045 & 0.42 & 0.63 \\
\hline $\begin{array}{l}\text { Vihannekset ja hedelmät } \\
\text { Vegetables and fruits }\end{array}$ & 8.8 & 0.564 & $(0.036)$ & 5.81 & 0.033 & $(0.003)$ & 0.617 & 0.09 & 0.90 \\
\hline $\begin{array}{l}\text { Lihatuotteet } \\
\text { Meat products }\end{array}$ & 16.8 & 0.334 & $(0.035)$ & 10.98 & 0.035 & $(0.003)$ & 0.346 & 0.03 & 1.07 \\
\hline $\begin{array}{l}\text { Kalatuotteet } \\
\text { Fish products }\end{array}$ & 3.0 & 0.116 & $(0.096)$ & 1.97 & 0.045 & $(0.012)$ & 0.256 & 0.55 & 2.99 \\
\hline $\begin{array}{l}\text { Munat } \\
\text { Eggs }\end{array}$ & & & & 2.02 & 0.032 & $(0.012)$ & 0.177 & 0.83 & 8.72 \\
\hline $\begin{array}{l}\text { Maitotaloustuotteet } \\
\text { Milk products }\end{array}$ & 16.4 & 0.323 & $(0.028)$ & 10.71 & 0.034 & $(0.003)$ & 0.343 & 0.06 & 0.95 \\
\hline $\begin{array}{l}\text { Voi } \\
\text { Butter }\end{array}$ & 8.6 & 0.184 & $(0.044)$ & 5.62 & 0.012 & $(0.003)$ & 0.232 & 0.21 & 1.06 \\
\hline $\begin{array}{l}\text { Rasvat ja öljyt } \\
\text { Fats and oils }\end{array}$ & & & & 1.56 & 0.011 & $(0.009)$ & 0.077 & 1.34 & 3.67 \\
\hline $\begin{array}{l}\text { Virvoitusjuomat } \\
\text { Non-alcoholic beverages }\end{array}$ & 8.9 & 0.579 & $(0.056)$ & 5.82 & 0.034 & $(0.003)$ & 0.634 & 0.09 & 0.97 \\
\hline $\begin{array}{l}\text { Alkoholijuomat } \\
\text { Alcoholic beverages }\end{array}$ & 3.0 & -0.292 & $(0.195)$ & & & & & & . \\
\hline Ravintola-ateriat & 4.2 & 2.077 & $(0.194)$ & 2.76 & 0.551 & $(0.071)$ & 2.155 & -0.04 & 0.84 \\
\hline Meals outside home & & & & & & & & & \\
\hline $\begin{array}{l}\text { Muu ravinto } \\
\text { Other food }\end{array}$ & 1.4 & 0.484 & $(0.098)$ & 0.92 & 0.058 & $(0.011)$ & 0.682 & 0.29 & 1.10 \\
\hline Tupakka & & 0.858 & $(0.145)$ & 3.65 & 0.031 & $(0.003)$ & 0.921 & 0.07 & 1.34 \\
\hline Tobacco & & & & & & & & & \\
\hline Vaatetus & & 0.982 & $(0.042)$ & 20.60 & 0.208 & $(0,014)$ & 1.097 & 0.10 & 0.91 \\
\hline
\end{tabular}


Taulukko 4. Määräjousto

Table 4. Quantity elasticity

Kaikki 2-lapsiperheet, $\mathrm{n}=105$

All families with 2 children

Hyödỵke

Kaksoislog.

Semilog.

Commodity

Double-log adjustment

Semi-log adjustment

$\bar{y}^{5} \quad \mathrm{~b} \quad \mathrm{~d} \quad \mathrm{~b}^{*} \frac{\mathrm{b}^{*}-\mathrm{b}}{\mathrm{b}^{*}} \frac{\mathrm{R} *}{\mathrm{R}}$

\begin{tabular}{|c|c|c|c|c|c|c|c|c|}
\hline Vehnä & 50.30 & -0.062 & $(0.037)^{3}$ & -0.0024 & $(0.0015)$ & -0.052 & -0.19 & 0.94 \\
\hline \multicolumn{9}{|l|}{ Wheat } \\
\hline Riisi & 2.91 & & & 0.0284 & $(0.0070)$ & 0.092 & 0.47 & 0.99 \\
\hline Rice & \multicolumn{3}{|l|}{ t } & & & & & \\
\hline Muu vilja & 28.10 & -0.123 & $(0.065)$ & -0.0512 & $(0.0214)$ & -0.198 & 0.38 & 1.26 \\
\hline \multicolumn{9}{|l|}{ Other cereals } \\
\hline Peruna & 70.60 & -0.222 & $(0.053)$ & -0.0105 & $(0.0028)$ & -0.162 & -0.37 & 0.91 \\
\hline \multicolumn{9}{|l|}{ Potatoes } \\
\hline Sokeri & 28.80 & & & 0.0130 & $(0.0087)$ & 0.049 & 0.43 & 1.88 \\
\hline \multicolumn{9}{|l|}{ Sugar } \\
\hline Herneet & 1.79 & -0.332 & $(0.103)$ & -0.0513 & $(0.0200)$ & -0.317 & -0.05 & 0.81 \\
\hline \multicolumn{9}{|l|}{ Pulses } \\
\hline Tuoreet vihannekset & 14.60 & 0.267 & $(0.054)$ & 0.0436 & $(0.0081)$ & 0.345 & 0.23 & 1.06 \\
\hline \multicolumn{9}{|l|}{ Fresh vegetables } \\
\hline Tuoreet hedelmät & 24.40 & 0.673 & $(0.047)$ & 0.1622 & $(0.0152)$ & 0.723 & 0.07 & 0.89 \\
\hline \multicolumn{9}{|l|}{ Fresh fruits } \\
\hline Naudan- ja vasikanliha & 16.50 & 0.270 & $(0.050)$ & 0.0435 & $(0.0066)$ & 0.287 & 0.06 & 1.16 \\
\hline \multicolumn{9}{|l|}{ Meat and veal } \\
\hline Sianliha & 15.00 & -0.124 & $(0.052)$ & -0.0122 & $(0.0060)$ & -0.088 & -0.41 & 0.85 \\
\hline \multicolumn{9}{|l|}{ Pork } \\
\hline Teurastuotteet & 1.33 & 0.386 & $(0.174)$ & 0.0461 & $(0.0154)$ & 0.376 & 0.03 & 1.32 \\
\hline \multicolumn{9}{|l|}{ Offal } \\
\hline Munat & 7.99 & 0.461 & $(0.044)$ & 0.0342 & $(0.0032)$ & 0.465 & 0.01 & 1.01 \\
\hline \multicolumn{9}{|l|}{ Eggs } \\
\hline Kala & 9.92 & 0.107 & $(0.058)$ & 0.0154 & $(0.0051)$ & 0.169 & 0.37 & 1.59 \\
\hline \multicolumn{9}{|l|}{ Fish } \\
\hline Täysmaito & 218.00 & 0.065 & $(0.038)$ & 0.0179 & $(0.0066)$ & 0.089 & 0.27 & 1.57 \\
\hline \multicolumn{9}{|l|}{ Full milk } \\
\hline Juusto & 2.82 & 0.682 & $(0.106)$ & 0.3255 & $(0.0636)$ & 0.245 & -1.78 & 0.84 \\
\hline \multicolumn{9}{|l|}{ Cheese } \\
\hline Voi & 14.40 & 0.179 & $(0.044)$ & 0.0301 & $(0.0069)$ & 0.052 & -2.38 & 1.07 \\
\hline \multicolumn{9}{|l|}{ Butter } \\
\hline Kerma & 7.58 & 0.725 & $(0.140)$ & 0.0462 & $(0.0058)$ & 0.662 & -0.10 & 1.36 \\
\hline \multicolumn{9}{|l|}{ Cream } \\
\hline Margariini & 6.48 & & & 0.0044 & $(0.0036)$ & 0.060 & 1.77 & -2.23 \\
\hline
\end{tabular}

Margarine 
Taulukko 5. Rahamenojousto

Table 5. Expenditure elasticity

2-lapsiset työläisperheet, $\mathrm{n}=\mathbf{7 6}$

Working class families with 2 children

Hyödyke

Kaksoislog.

Semilog.

Commodity

Double-log adjustment

Semi-log adjustment

$\begin{array}{cccc}\%^{1} & \text { b } & \bar{y}^{2} & \text { d }\end{array}$

100.0

$0.433(0.028)^{3}$

64.40

$0.025(0.002)$

0.422

$-0.03$

0.99

Total food

Leipä- ja viljatuotteet

14.6

$0.218(0.055)$

9.40

$0.017(0.005)$

$0.196-0.11$

0.95

Bread and cereals

Sokeri

6.0

$0.255(0.058)$

3.87

$0.010(0.002)$

0.281

0.09

1.18

Herneet ym.

0.3

$0.332(0.050)$

0.19

$0.062(0.010)$

0.346

$0.40 \quad 0.94$

Pulses etc.

Vihannekset ja hedelmät

$\begin{array}{lllllllll}8.6 & 0.417 & (0.045) & 5.52 & 0.022 & (0.003) & 0.433 & 0.04 & 0.95\end{array}$

Vegetables and fruits

Lihatuotteet

17.0

$0.434(0.036)$

11.00

$0.043(0.004)$

$\begin{array}{lll}0.427 & -0.02 \quad 1.00\end{array}$

Meat products

Kalatuotteet

Fish products

Munat

$3.10 .448(0.047)$

1.98

$0.084(0.010)$

0.462

$0.03 \quad 0.96$

3.1

$0.482(0.074)$

2.00

$0.080(0.013)$

$\begin{array}{lll}0.434 & -0.11 \quad 0.98\end{array}$

Eggs

16.7

$0.351(0.028) \quad 10.81 \quad 0.034(0.003)$

$\begin{array}{lll}0.342 & -0.03 \quad 1.00\end{array}$

Milk products

Voi

8.9

$0.290(0.032)$

$5.75 \quad 0.015(0.002)$

0.283

$-0.02$

1.00

Virvoitusjuomat

$8.90 .759(0.056)$

$5.71 \quad 0.042(0.003)$

0.799

$0.05 \quad 0.97$

Non-alcoholic beverages

Alkoholijuomat

3.

$0.908(0.271)$

$1.970 .014(0.005)$

$\begin{array}{lll}0.772 & -0.18 & 0.92\end{array}$

Alcoholic beverage:

Ravintola-ateriat

Meals outside home

3.8

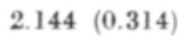

2.46

$0.378(0.061)$

1.671

$-0.28$

0.94

Tupakka

$1.374(0.475)$

3.43

$0.040(0.003)$

1.268

$\begin{array}{ll}-0.08 & 1.04\end{array}$

$1.098(0.070)$

$19.5 \quad 0.227 \quad(0.025)$

1.261

$0.13 \quad 0.83$

Vaatetus

Clothing 
Taulukko 6. Määräjousto

Table 6. Quantity elasticity

2-lapsiset työläisperheet, $\mathrm{n}=76$

All wage earner families with 2 children

Hyödyke

Kaksoislog.

Semilog

Commodity

Double-log adjustment Semi-log adjustment

$\bar{y}^{5} \quad \mathrm{~b} \quad \mathrm{~d} \quad \mathrm{~b}^{*} \quad \frac{\mathrm{b}^{*}-\mathrm{b}}{\mathrm{b}^{*}} \frac{\mathrm{R}}{\mathrm{R}}$

Riisi

2.98

$0.0328(0.0342)$

0.120

$1.13-7.55$

Rice

Muu vilja

Other cereals

Sokeri

28.90

$-0.268(0.086)^{3}$

$-0.1059(0.0304)$

$-0.398$

$0.33-1.10$

Sugar

Herneet

Pulses

Tuoreet vihannekset

29.10

$0.094(0.052)$

$0.0032(0.0013)$

0.120

0.22

1.34

Fresh vegetables

Tuoreet hedelmät

$1.87-0.324(0.104)$

$-0.0945(0.0258) \quad-0.542$

0.40

1.16

Fresh fruits

Naudan- ja vasikanliha

14.00

$0.103(0.070)$

$0.0212(0.0080)$

0.165

0.38

1.73

23.20

$0.661(0.064)$

$0.1484(0.0167)$

0.694

0.05

0.93

16.50

$0.458(0.055)$

$0.0672(0.0082)$

$0.442-0.04$

0.99

Sianliha

15.70

$0.110(0.050)$

$0.0139(0.0070)$

$0.096 \quad-0.15 \quad 0.91$

Pork

Teurastuotteet

1.24

$0.734(0.218)$

$0.0370(0.0162)$

$0.324-1.27$

0.70

Munat

7.93

$0.477(0.072)$

$0.0312(0.0048)$

$\begin{array}{lll}0.427 & -0.12 \quad 0.99\end{array}$

Kala

10.06

$0.116(0.061)$

$0.0153(0.0057)$

0.165

$0.30 \quad 1.38$

Täysmaito

225.00

$0.122(0.060)$

$0.0347(0.0100)$

0.168

$0.27 \quad 1.62$

Full milk

Juusto

2.25

$0.088(0.101)$

$0.0216(0.0231)$

0.104

$0.15 \quad 1.07$

Cheese

Voi

$14.70 \quad 0.281(0.032)$

$0.0381(0.0043)$

0.281

$0.00 \quad 1.00$

Butter

Kerma

7.97

$1.320(0.144)$

$0.0709(0.0056)$

0.966

$0.37 \quad 1.13$

Cream

Margariini

6. 17

$-0.0035(0.0037) \quad-0.062$

$0.15 \quad 1.16$

Margarine 


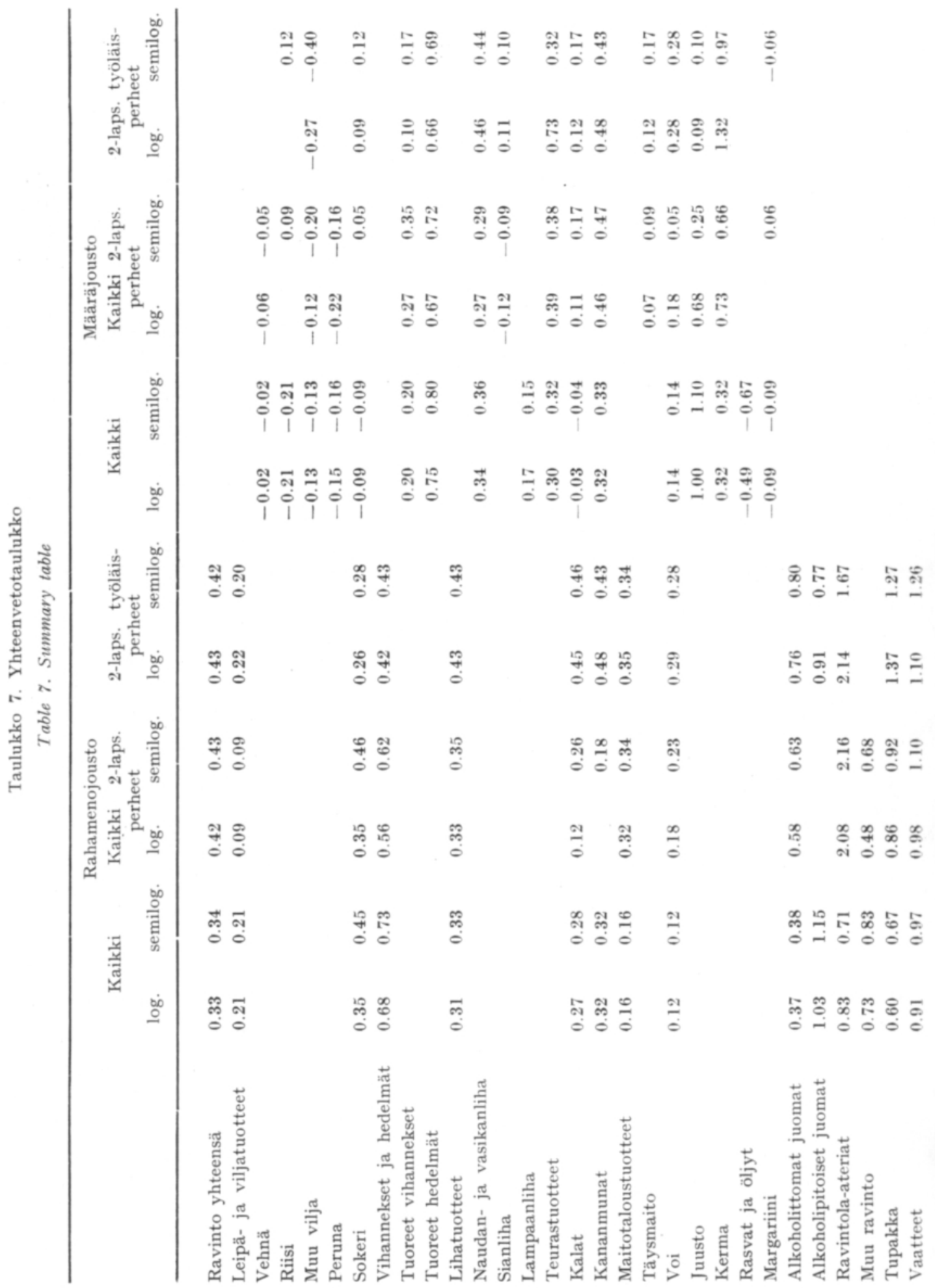


(1) Brows, J. A. C. The consumption of food in relation to household composition and income. Econometrica 22, 1954: 444-460.

(2) Gollsick, H. Ausgaben und Verbrauch in Abhängigeit von Einkommen und Haushaltsstruktur. Agrarwirtschaft 6/7 1959, $264 \mathrm{~s}$.

(3) Goreux, L. Income elasticity of the demand for food. Household survey analysis. FAO. Rome 1959. $150 \mathrm{~s}$.

(4) Prais, S. J. ja Houthakker, H. S. The analysis of family budget, with an application to two British surveys conducted in $1937-39$ and their detailed results. Cambridge 1955, $372 \mathrm{~s}$.

S U M M A R Y :

INCOME ELASTICITY OF FOOD EXPENDITURE AND CONSUMPTION

PaAvo KaARlehto

Agricultural Economics Research Institute, Rukkila

In this study the relationships between income and food consumption are analysed on the basis of data collected for the 1956 household survey in Finland. Supported by calculation results the author indicates that in order to get reliable estimates for elasticity coefficients 1) the form of the demand function deserves special attention, especially in the case of the food items with high fat content 2) stratification of data is necessary on the basis of a) size of household and b) social class of the family. As in this case it was impossible to obtain complete sets of stratified data for proper covariance analysis, estimates for the elasticity coefficients were calculated separately from unclassified data, from data on all families with two children and from data on worker-families with two children. These elasticity coefficients, as computed in the FAO, are given in Tables $1-6$ for comparision. 